\title{
Measurement of Trace Rainfall at a High Arctic Site
}

\author{
MING-KO WOO AND PETER STEER ${ }^{1}$
}

\begin{abstract}
Trace rainfall is defined as rainfall under $0.2 \mathrm{~mm}$ (or $0.05 \mathrm{in}$ ) which cannot be measured by conventional types of rain-gauges. In the Canadian Arctic Islands, trace rainfall is commonly reported by the government weather stations or by researchers in the field. Frequent occurrence of such events is attributed to the moisture provided by the open water areas and melting snow (Barry and Hare, 1974). To date, however, the measurement of trace rainfall has not been attempted. In view of low rainfall in the High Arctic, the exclusion of trace rainfall can possibly cause an underestimation of summer precipitation (Courtin and Labine, 1977; Jackson, 1961). The purpose of the present study is to determine the magnitude of several trace rainfall events using a simple device modified after one designed to study fog (Burton, 1971).
\end{abstract}

\section{Study method and study site}

The device to measure trace rainfall consists of a sheet of aluminium measuring $34 \mathrm{~cm} \times 44 \mathrm{~cm}$, glued on a plywood board $(1 \mathrm{~cm}$ thick) for reinforcement. The board rests horizontally on a pedestal of four half buried cans slightly raised above the ground to avoid rain splash. Onto the board is placed a wad of pre-weighed absorbent paper (commercially available paper towel was used) which are held down by an aluminium frame, $2 \mathrm{~cm}$ wide, that fits over the board. Several picture-framing wires are strung across the frame to ensure flatness of the paper (Fig. 1). Depending on the intensity of the trace rainfall event, the paper towels are exposed for a period of several hours. Under no circumstances is the paper left on the board for more than one hour after the rain has terminated. This reduces the possibility of excessive evaporation, although evaporation can sometimes occur when the moist paper towels are exposed on the board. Since some evaporation is unavoidable, the measurement thus obtained represents a minimum value for trace rainfall.

When the paper is taken off the board, it is quickly sealed in a preweighed plastic bag, and brought back to base camp for weighing. In the field, an Ohaus triple-beam balance was used. The re-weighing of a sample by a Mettler balance showed that the triple-beam balance was accurate to within $0.1 \mathrm{gm}$, representing a possible error of under $2 \%$.

After weighing, trace rainfall is obtained by

$$
\left[\left(W_{w}-W_{b}\right)-\left(W_{d}-W_{b}\right)\right] / \rho A
$$

where $W_{w}$ and $W_{d}$ are the weights of the plastic bag and the absorbent paper when wet and when dry (in gm)

$W_{b}$ is weight of the plastic bag used to hold the paper (in gm)

$A$ is the area of the board exposed to the trace rainfall (in $\mathrm{cm}^{2}$ ) $\rho$ is density of water, taken as $1 \mathrm{gm} / \mathrm{cm}^{3}$.

${ }^{1}$ Department of Geography, McMaster University, Hamilton, Ontario 


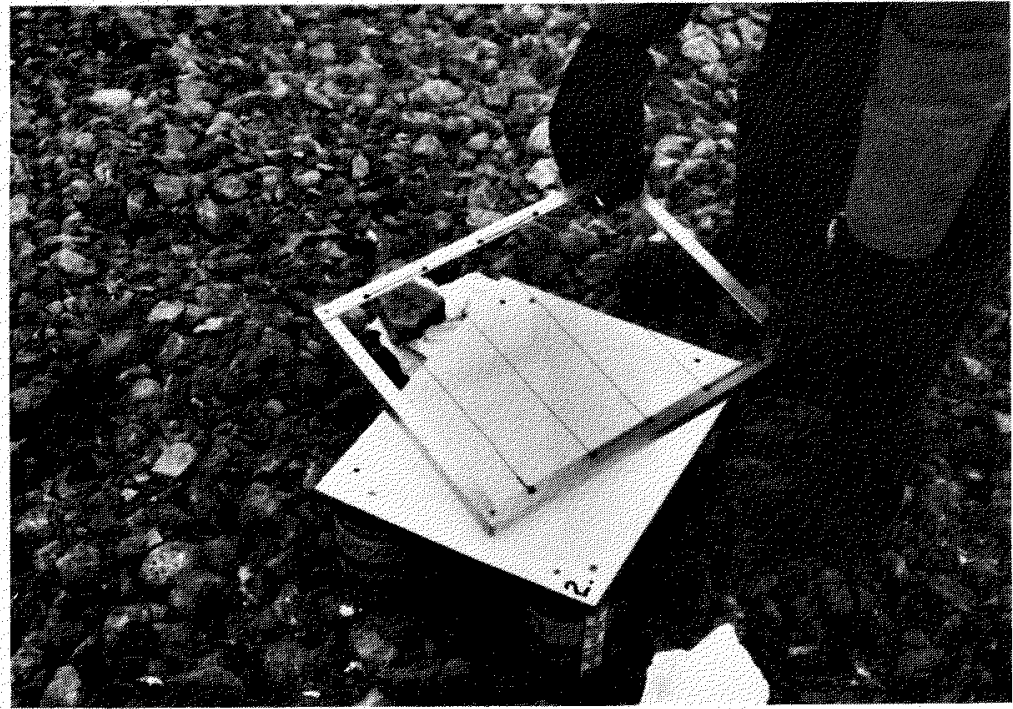

FIG. 1. Trace rainfall measurement device mounted on a pedestal of four half-buried tin cans. To measure trace rainfall, a wad of absorbent paper is placed onto the aluminium board and held down by the frame.

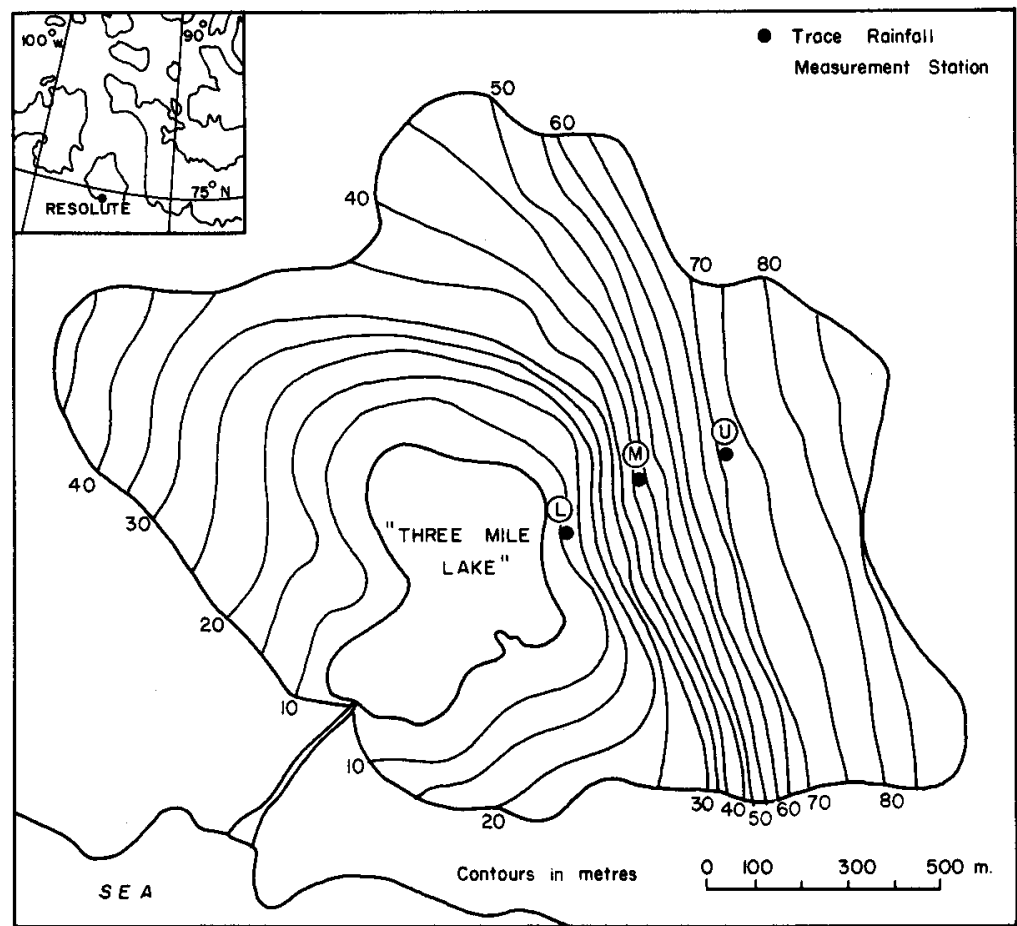

FIG. 2. The study site five kilometres northwest of Resolute showing a small coastal basin in which the west-facing slope is located. Trace rainfall measurement devices were set up at elevations of $11 \mathrm{~m}$ (Station L), $42 \mathrm{~m}$ (Station M) and $72 \mathrm{~m}$ (Station $\mathrm{U}$ ) aboe sea level. 
TABLE 1 Summary of trace rainfall events studied at the test site northwest of Resolute during the summer of 1978

\begin{tabular}{|c|c|c|c|c|c|c|c|}
\hline Beginning & $\begin{array}{l}\text { Event } \\
\text { Ending }\end{array}$ & $\begin{array}{c}\text { Wind } \\
\text { Direction }\end{array}$ & Station & $\begin{array}{c}\text { Total } \\
\text { Rainfall } \\
(\mathrm{mm})\end{array}$ & $\begin{array}{c}\text { Rainfall } \\
\text { Intensity } \\
(\mathrm{mm} / \mathrm{h})\end{array}$ & $\begin{array}{c}\text { Mean } \\
\text { Intensity } \\
(\mathrm{mm} / \mathrm{h})\end{array}$ & $\begin{array}{c}\text { Standard } \\
\text { Deviation } \\
(\mathrm{mm} / \mathrm{h})\end{array}$ \\
\hline 0930 July 24 & 2015 July 24 & $130^{\circ}$ & $\begin{array}{l}\mathrm{L} \\
\mathbf{M} \\
\mathbf{U}\end{array}$ & $\begin{array}{l}0.0274 \\
0.0224 \\
0.0249 \\
\end{array}$ & $\begin{array}{l}0.0028 \\
0.0023 \\
0.0026 \\
\end{array}$ & 0.0026 & 0.00026 \\
\hline 1400 July 29 & 2045 July 29 & $315^{\circ}$ & $\begin{array}{l}\mathbf{L} \\
\mathbf{M} \\
\mathrm{U} \\
\end{array}$ & $\begin{array}{l}0.0398 \\
0.0407 \\
0.0290 \\
\end{array}$ & $\begin{array}{l}0.0059 \\
0.0060 \\
0.0043 \\
\end{array}$ & 0.0054 & 0.00096 \\
\hline $\begin{array}{l}1000 \text { Aug. } 3 \\
1830 \text { Aug. } 2\end{array}$ & 1830Aug. 3 & $314^{\circ}$ & $\begin{array}{l}\mathbf{L} \\
\mathbf{M} \\
\mathbf{U} \\
\mathbf{L} \\
\mathbf{M} \\
\mathbf{U} \\
\end{array}$ & $\begin{array}{l}0.2158 \\
0.1900 \\
0.2183 \\
0.1030 \\
0.1330 \\
0.1510 \\
\end{array}$ & $\begin{array}{l}0.0254 \\
0.0224 \\
0.0257 \\
0.0054 \\
0.0070 \\
0.0080 \\
\end{array}$ & 0.0068 & 0.00184 \\
\hline 0900 Aug. 10 & 1245 Aug. 10 & $170^{\circ}$ & $\begin{array}{l}\mathbf{L} \\
\mathbf{M} \\
\mathbf{U}\end{array}$ & $\begin{array}{l}0.0631 \\
0.0680 \\
0.0722\end{array}$ & $\begin{array}{l}0.0168 \\
0.0181 \\
0.0193\end{array}$ & 0.0181 & 0.00121 \\
\hline
\end{tabular}

Overall mean 0.0115

L Lower station, elevation $11 \mathrm{~m}$

M Middle station, elevation $42 \mathrm{~m}$

U Upper station, elevation $72 \mathrm{~m}$ 
A west-facing slope of a small coastal basin located five $\mathrm{km}$ northwest of Resolute Airport, Cornwallis Island, N.W.T., was selected as the study site. The site was chosen because of its proximity to a first-class weather station which reports six-hourly precipitation. At the site, three trace rainfall measurement devices were set up at elevations of 11,42 and $72 \mathrm{~m}$ above sea level. These are stations labelled $L, M$ and $U$ respectively in Figure 2. In addition, a Weather Measure tipping-bucket rain-gauge was placed adjacent to station $\mathrm{L}$ to provide conventional type of rainfall data. Seven sets of test measurements were made in the summer of 1978. Two of these tests were abandoned because the rain-guage record indicated that trace rainfall turned into light drizzle.

\section{Results and discussion}

Results of the tests are given in Table 1. The data yield the following tentative findings.

(1) Although trace rainfall cannot be measured by conventional rain-gauges, it can be collected by absorbent paper. Results from the five test runs indicate a mean intensity of $0.01 \mathrm{~mm} / \mathrm{hr}$. However, trace rainfall intensity varied considerably between the five events studied, ranging from 0.003 to 0.025 $\mathrm{mm} / \mathrm{hr}$. For a given trace rainfall event, the three stations usually showed similar rainfall intensity, with a standard deviation averaging $0.001 \mathrm{~mm} / \mathrm{hr}$. There was no systematic difference in trace rainfall between individual stations. Without adequate data, it is not possible to interpret the spatial variation in terms of topography and wind direction.

(2) Spatial variation of trace rainfall can be visually observed when localized fog or low clouds roll inland from the open sea. Further evidence is furnished by the rainfall event of August 3-4. During these days, trace rainfall prevailed at the test site and the recording rain-gauge at the site did not register any measurable rainfall. On the other hand, five kilometres away, the weather station of Resolute recorded $0.6 \mathrm{~mm}$ rainfall between $0600 \mathrm{hr}$ and $1800 \mathrm{hr}$ on August 3, and $0.3 \mathrm{~mm}$ from $1800 \mathrm{hr}$ till $1200 \mathrm{hr}$ of the following day. Such spatial variability of trace rainfall is to be expected in view of the distance between sites and the localized nature of some rainfall events.

(3) Despite the low trace rainfall intensity obtained, total seasonal contribution can be important. For the Resolute weather station, the six-hourly precipitation record reported 36 periods of trace rainfall in the summer of 1976,51 periods in 1977, and 46 periods in 1978. Assuming a mean rainfall intensity of $0.01 \mathrm{~mm} / \mathrm{hr}$ and taking a conservative estimate that half of the six hours within each period received trace rainfall, its annual contribution in the above three years totalled $1.08 \mathrm{~mm}, 1.53 \mathrm{~mm}$ and $1.38 \mathrm{~mm}$ respectively. For a wet summer like $1978,1.38 \mathrm{~mm}$ did not add much to total rainfall but the recorded total for 1976 was $32.2 \mathrm{~mm}$ and for 1977 , it was only $9.2 \mathrm{~mm}$. Trace rainfall then represents 3 and $17 \%$ of the total rainfall recorded by the weather station.

\section{Summary}

This study demonstrates that trace rainfall in the Arctic Archipelago can be determined in the same way as fog and dew is measured in the more southerly 
latitudes. Our limited data suggests that the intensity of trace rainfall is both temporally and spatially variable. However, using an empirically obtained mean intensity of $0.01 \mathrm{~mm} / \mathrm{hr}$, it was found that trace rainfall constitutes a significant portion of total summer rainfall during the drier years.

\section{ACKNOWLEDGEMENTS}

Financial support for this project was provided by a Natural Sciences and Engineering Research Council of Canada grant, and a Water Resources Research Support Programme grant from the Inland Waters Directorate, Environment Canada. Generous logistical support was offered by the Polar Continental Shelf Project, Canadian Department of Energy, Mines and Resources.

\section{REFERENCES}

BARRY, R. G. and HARE, F. K. 1974. Arctic climate. In Ives, J. D. and Barry R. G. (Eds.) Arctic and Alpine Environments, Methuen. 17-54.

BURTON, R. E. 1971. A weatherman looks at the redwood tree: California's "fog drinker".

Weatherwise, 24: 120-124.

COURTIN, G. M. and LABINE. C. L. 1977. Microclimatological studies on Truelove Lowland. In Bliss, L. C. (Ed.) Truelove Lowland, Devon Island, Canada: a high Arctic Ecosystem. Univ. of Alberta Press, 73-106.

JACKSON, C. I. 1961. Summer precipitation in the Queen Elizabeth Islands. Folia Geog. Danica, 9 140-153. 